\title{
第13回 急性肝不全治療研究会抄録
}

\section{主題(1) 多臟器不全 (MOF) に占める 肝不全の意義}

\section{1. 多臓器不全における肝不全の意義について の検討}

皮阜大学第 1 内科

村上 啓雄, 西尾優, 白子 順子

高木 昌一, 杉原 潤一, 中村 俊之

大西 弘生, 斉藤公志郎, 冨田 栄一

武藤 泰敏

岐阜県立岐阜病院消化器科

瀬古 章, 清水 勝

対象症例は多藏器不全 (MOF) 45例と劇症肝炎で多 䁍器不全合併例 (FH) 56例. MOF 症例45例中24例 (53.3\%)に肝障害がみられ，不全荿器数が 4 つ以下の MOF に扎いては肝障害は他のいずれの葴器不全より 頻度が低かった，MOF 肝障害合併例と FHに㧊ける 他の喊器不全の合併率を比較すると，肺，心，堅の不 全は MOF 肝障害の方が高率であり，凝固系，中枢神 経, 消化管の不全は FH の方が高率であった. MOF 肝 障害は, $\mathrm{TB}<5.0 \mathrm{mg} / \mathrm{d} l$ の症例 $73.9 \% \mathrm{HPT}>40 \%$ の 症例 $55.6 \%$ なと比較的軽度のむのが多く，劇症肝炎に 匹敵する程度の肝障害は少数であり，また心あるいは 肺の不全の先行が多く，剖検組織所見でる小葉中心性 の罗死がみられ，肝の hypoperfusion あるいは hypoxiaが一因となるすのと推察された。

2. 多腀器不全 (MOF) の key organ としての 肝婼の重要性について 千葉大学救急部・集中治療部

荌井 桂雄, 志賀 英敏, 青江 知彦 稲葉 英夫, 平澤 博之

同 第 2 外科 田畑陽一郎，小高 通夫 今回 MOF 症例の生存例と死亡例を比較する事に上 り MOF の死因につながる key organ としての肝䁍 の重要性につき検討した，MOF 症例の肝不全の合併 率は, 死亡群は, 生存群に比し有意に高率であった。

\author{
会 期：昭和62年 6 月 13 日（土） \\ 会 場：岡山プラザホテル \\ 世話人：長島 秀夫（岡山大学第 1 内科）
}

中枢神経障害, 消化管出血 む, 死亡群では有意に高率 に見られ，中枢神経障害の $93 \% か ゙$ 肝不全に続発してお。 り，消化管出血は全例肝不全に続発していた。 また MOF 発症時に打いて, 死亡例は生存例に比し, 動脈血 中ヶトン体比（AKBR）は有意に低值であり，Osmolality Gapは有意に高值であった。これ等の結果 は, 多葴器不全症例に执いて, 生死をわける key organ としての肝臓の重要性を示唆するるのと考えられた。

\section{3. 多臓器不全患者における肝障害の検討} 久留米大学第 2 内科 赤司 隆裕, 神代 龍吉, 力武 潔 古賀有利子, 安倍 弘彦, 谷川 久一 同 救命救急センター

筆崎 正博, 加来 信雄 MOF を呈して死亡した14例について肝組織所見及 び臨床所見を検討した。対象は主に腹部手術後の MOFで劇症肝炎や肝硬変合併例は除いた，肝組織像 にて帯状壊死以上の広い壊死像を 8 例に認めた。猡死 部の境界が比較的鮮明で小葉中心性の凝固壊死が多 く，円形細胞浸潤は少なかった，PT，HPT は低下傾 向はみられたが，劇症肝炎の基準を満たするのは少な く，肝重量はむしろ増加している例すみられた，以上 よりMOFでは急性肝不全と異なり，肝不全が直接の 死因となる事は少ないと考兄られた。肝壊死像が少な い症例で高度の黄㾞とリムルステスト強陽性を呈する すのがみられ，肝内胆汁うっ滞の機序としてェンドト キシン血症の関与が示唆された。

\section{4. 急性肝不全死亡例における多朖器不全の検} 討

東京慈恵会医科大学第 1 内科

樺恵, 石沢 和敬, 戸島恭一郎

植松 幹雄, 山崎 一信, 広沢 恵生

今井 深, 亀田 治男

3 贜器以上の障害を呈するすのを MOF とし急性肝 不全死亡例 8 例について検討した。対象症例は劇症肝 
炎亜急性型 4 例, acute-on-chronic 2 例, キャリア劇症 化 1 例, LOHF 1 例である.急性肝不全発症より MOF 出現までの期間の検討では acute-on-chronic で，ょり 早期に MOF が出現する傾向を認めた。合併頻度では ARDS，中枢神経障害，DIC が多く認められた。消化 管出血は $\mathrm{H}_{2}$-ブロッカー投与例で有意に少なかった。 病理学的検討では腎では糸球体に变化を認めないが近 位尿細管に壇死を伴なわない著明な水腫様変性を認め た. DICを示唆する腎, 肺の微小血栓は25\%に認めた。 肺では肺胞内出血，肺うっ血が50\%にみられた。他に 心，消化管，脳汅は特徵的所見を見出さなかった。

\section{5. 多臓器不全を伴った肝不全症例の検討} 人工臟器移植研究所 $\cdot$ 札幌北榆病院外科

\section{目黒 順一，久木田和丘}

米川 元樹，川村 明夫

同 内科

今井 陽俊, 小林 直樹

川村 憲一，笠井 正晴

対象症例は劇症肝炎12例中11例 $(91.7 \%$ ), 肝硬変症 20例中16例 (80\%) である，不全臓器別では ARF，中 枢神経障害が比較的多く，とりわけ劇症肝炎ではより 高率であり，かつ重篤であった。 また不全臓器数では 4 葴器にわたる例が劇症肝炎で 7 例 (63.6\%) で，肝 硬変症の 4 例（25\%）より明らかに高率であった， 4 臟器にわたる例での救命例はなく, 劇症肝炎で 3 臓器 障害の 2 例 (18.2\%) を救命した，肝硬变症は合併症 も比較的軽度で，肝不全死が多いが，劇症肝炎では脳 浮腫から脳死へ移行する例むみられ，有効な肝補助シ ステムの開発と, 中枢神経障害の治療が今後の重要な 課題と思われる.

6. 劇症肝炎における多臓器不全 (MOF) と術 後 MOF の臨床病像の差異について

岡山大学第 1 内科

塩田 哲也, 吉田 康博, 橋本 誠

冨永 知, 小林 道男, 東 俊宏

渡辺 明治, 辻 孝夫

川鉄水島病院

長島 秀夫

劇症肝炎 9 例と, 術後肝不全を合併した肝硬変手術 例 7 例について, 死亡までの経過中に発生した臓器不 全の病像の差異を検討した，劇症肝炎例では全例，肝 硬变手術例では 4 例に MOF を合併し，その平均臓器 不全数はそれぞれ4.9個と，3.6個であった，劇症肝炎 例では各臓器不全の発生頻度が高く, 肝硬変手術例比
比べて特に消化管出血（67\%）が多い傾向にあった， 肝硬変手術例の肝不全発現時期は比較的荤く（術後平 均21日)，血清ビリルビン值の上昇も劇症肝炎に此べて 緩徐だった，死亡直前に新たに加わった臓器不全は劇 症肝炎では腎不全 (56\%) や消化管出血 (33\%) が, 肝硬变手術例では心不全 (57\%) p肝不全 $(29 \%)$ が 多く，その予後に大きく影響していると考えられた。

\section{7. 消化器外科症例における MOF 発生例, 特 に肝不全の占める意義 \\ 三重大学第 1 外科 \\ 野口孝, 酒井 秀精, 中川 俊一 \\ 横井一, 川原田嘉文, 水本 龍二}

最近10年半に教室で経験した消化器外科手術例1983 例中 MOF 発生例は33例 (1.7\%) で，術前合併肝病変 ありのものや肝切除例に多く，救命率は肝不全を合併 しない MOF 症例11例では45.5\%，肝不全のみの16例 では $18.8 \%$ ，肝不全合併 $\mathrm{MOF}$ 症例22例では9.1\%で あった。肝不全合併 MOF 症例の臟器障害発現率は, 心 不全が肝不全発生前に $42.9 \%$ と高率で，逆に消化管出 血は肝不全発生後に66.7\% と高かったが，肺及び腎不 全は肝不全発生時期に関係なく 65 ８0\%に認めた。す なわち，術後の心肺腎の詳細な intensive care のみな らず，MOF の主な原因である術前高度肝障害や術式 過大, 感染症に対して, riskに従った適切な術式の選 択, 網内系機能を中心とした術前術後管理は, これら 症例の外科治療上極めて重要である.

\section{8. 急性腎不全時の肝障害について 千葉大学第 2 外科 \\ 田畑陽一郎，小高 通夫，小林 弘忠 添田 耕司，林 春幸，今関 英男 吉田 正美, 朝長 毅, 藤井 京子 磯野 可一 \\ 同 救急部集中治療部}

平澤 博之，菅井 桂雄

当科に扔ける急性堅不全 (ARF) の多臓器不全 (MOF)の予後を retrospective に各不全藏器, 特に肝 障害および感染症との関係について検討し，MOF へ の増悪因子を検索した，結果：昭和42年より62年 4 月 までの ARF 症例は166例で，この内110例を救命し， MOF は118例であった，肝障害合併例 (H 群) は46例 であり，感染症合併例 (I 群)は，88例であった，H群 と非 $\mathrm{H}$ 群間では予後に有意差はないが， 3 不全蔵器以 
上になると H 群（救命率45\%）が非 H 群 (77\%) に比 して予後不良であった。一方，I群 (38\%)では非 I 群 （67\%）に比して予後不良であった，MOFの組み合せ で多いのは肝十肺，肺十消化管出血，肺十意識障害で あった。結語：ARFの MOFでは肝障害合併よりる感 染症合併がMOF 増悪因子としてより重要であった。

\section{主題(2) 肝不全における凝固系をめぐる 諸問題}

1. 急性肝不全患者の凝血学的検討

久留米大学第 2 内科

益子 直己, 南野 隆一, 緒方 秀

中野均, 力武潔, 赤司 隆裕

神代 龍吉, 安倍 弘彦, 谷川 久一

犬山シンポジゥムの劇症肝炎の基準をみたす急性肝 不全例 54 例に凝血学的検查を施行し下記の結果を得 た.

肝由来の凝固因子，ブラスミノーゲン，フンチトロ ンビンIIIの著減を認めた。 その原因として, 肝産生能 低下が考えられた。

入院時凝血学的検查で, 血小板数 8 万/ $\mu l$ 以下, プロ トロンビン時間 $20 \%$ 以下，トロンビン時間 25 秒以上， $\mathrm{FDP} 40 \mu \mathrm{g} / \mathrm{m} l$ 以上, フィブリノーゲン $100 \mathrm{mg} / \mathrm{d} l$ 以下 が予後不良の所見であった。

血小板数の推移は予後判定に有用であった。

入院時 DIC の合併に FDP $40 \mu \mathrm{g} / \mathrm{m} l$ 以上, 血小板数 8 万 $/ \mu l$ 以下, 硫酸プロタミン試験陽性が有用であっ た.

2. 肝全摘時における凝固能の変動一主として 血小板についてー

岐阜大学第 1 外科

松波 英寿, 鬼束 惇義, 千賀 省始

福富督, 矢野 好弘, 日野 晃紹

林 勝知, 広瀬 光男

同所性肝移植手術に用いられる門脈血，下大静脈血 を上大静脈へ灌流するハイイパス（以下 V.V bypass）を 使用して，イヌにおいて䀒全摘を施行し，無肝犬を作 成した。その際における凝固能の变動を検討した.V-V bypassを使用した無肝期に血小板の減少が見られる が，これはV-V bypass に起因する現象と思われる。 ADP, collagen 投与による血小板凝集能は無肝期に経 時的に減少した. TEGma は血小板凝集能と同様の変
動を示した. $\mathrm{TXB}_{2}$ は bypass 開始により高値を示し, 肝の存在下では持続的に高值となるが，無肝状態では 再び低下した。無肝状態では, PT, APTT が漸次延長 し, AT-III, antiplasmin は漸次減少し, FDPは全例 陽性となった。

3. $\alpha_{2}$ Plasmin Inhibitor · Plasmin · Complex を用いた劇症肝炎における DIC 診断 東京大学第 1 内科

$\begin{array}{rrrr}\text { 富谷 } & \text { 智明, 林 } & \text { 茂樹 } \\ \text { 藤原 } & \text { 研司, 岡 } & \text { 博 } \\ \text { 国立王子病院内科 } & \text { 井上 } & \text { 昇 }\end{array}$

DIC の診断が困難とされている肝疾患に打いて， $\alpha_{2}$ Plasmin Inhibitor (以下 $\alpha_{2} \mathrm{PI}$ ) 及び凝固線溶の元進時 に認められる $\alpha_{2}$ Plasmin Inhibitor - Plasmin - Complex (以下 $\alpha_{2} \mathrm{PI} \cdot \mathrm{Pm} \cdot \mathrm{C}$ ) をビーズ固定抗体之酵素標 識抗体による 1 step サンドイッチ法で測定し, 劇症肝 炎の DIC 確定診断における有用性を検討した. DICを 合併していない肝疾患において， $\alpha_{2}$ PI 值は肝合成能を 反映した。 $\alpha_{2} \mathrm{PI} \cdot \mathrm{Pm} \cdot \mathrm{C}$ は FDP と異なり腹水からの 移行は認められなかった。劇症肝炎において， $\alpha_{2}$ PI 低 值でる DIC 時に $\alpha_{2} \mathrm{PI} \cdot \mathrm{Pm} \cdot \mathrm{C}$ は陽性となり, 網内系 による除去も低下していなかった。 以上より $\alpha_{2} \mathrm{PI} ・$ $\mathrm{Pm} ・ \mathrm{C}$ は劇症肝炎における DIC を正確に反映すると 考えられ，確定診断に有用であると思われた。

4. 血奬交換療法が奏効した肝硬変合併 DIC の 1 例

$$
\begin{aligned}
& \text { 東北大学第 } 3 \text { 内科 } \\
& \text { 矢島 義昭, 鈴木 勃志, 大㭇 昌夫 } \\
& \text { 中山 晴夫, 森 和夫, 後藤 由夫 } \\
& \text { 東北大学第 } 1 \text { 外科 } \\
& \text { 松原 修二, 岡部 健二 }
\end{aligned}
$$

Gabexate mesilate が無効であった肝硬变合併 DIC 症例（61歳，女性）に対して血墏交換療法が奏効し, DICからの離脱ができた。本例においても, DICの出 現と non-septic endotoxemiaは密接な関係を示し, FDP と non-septic endotoxemia との間には全経過に おいて䫒著な平行関保が見られた。硫酸コンドロイチ ソ (CSFe) 負荷試験による絧内系貪食能は, DIC 出現 時には殆と破綻していたが，DIC 離脱後は著しく改善 していた。顆粒球エラスターゼは non-septic endotoxemia が比較的軽度であった DIC 出現時に最高值を示 したが，経過中必ずし non-septic endotoxemia とは 
相関を示さなかった，以上より，本例における DICの 合併は網内系不全と関係して和り, FDP と平行関係を 示した non-septic endotoxemia は網内系不全を表わ すパラメーターであると考えられた。

5. 劇症肝炎における肝再生とAT-III の動向 人工䏩器移植研究所 - 札幌北柡病院外科 川村 明夫, 目黒 順一 久木田和丘, 米川 元樹

同内科 今井 陽俊, 小林 直樹 川村 憲一，笠井 正晴

12例の劇症肝炎に血漿交換，血墏冷却濾過法，人工 透析などを行った。この際の AT-III を含め, 凝血因子 の動向を肝再生の面から検討した，劇症肝炎離脱例の 肝容積は $750 \mathrm{~m} l$ 以上で，それ以下の症例は死亡例之 なった。またこのときの AT-III あ離脱例で平均 $50 \%$ 以上，死亡例では25\%であった。肝容積と AT-IIIはこ のとき $\mathrm{r}=0.85$ の相関がみられた。 また，治療開始後 5 日目では肝容積とAT-III は0.65の相関がみられ，血 漿交換により AT-IIIが補われ，肝の機能そのすのを 反映しなくなっている，しかし，救命例では，肝容積 の増大・回復に伴い，AT-III 值の改善をみとめた。 た他の凝血因子群もほ注同様の傾向を示した。

\section{6. 劇症肝资に対する AT-III 製剤の使用経験} 愛媛大学第 3 内科

$$
\begin{array}{llrr}
\text { 多田 } & \text { 康二, 赤松 } & \text { 興一, 大嶋 完二 } \\
\text { 今野 敏伸, 木村 } & \text { 洸, 太田 康幸 }
\end{array}
$$

急性肝不全 9 例（劇症肝炎 6 例 - 覀急性肝炎 3 例） に対して AT-III 製剤3,000U/日を投与し，その臨床効 果について倹討した．AT-III 投与前の血墏 AT-III 值 は全例著明な低下を示したものの，代償性肝硬変と比 較して有意な差はなかった. しかし，AT-III 4,000Uを 1 時間で点滴静注した後の血獎 AT-III 值の経時的変 化から求めた initial half disappearance time は, DIC の合併がなくてる劇症肝资で著しく短縮している症例 が多く，壊死肝及び残存肝実質組織で AT-III が消費 され肝の很環を障害している可能性が考えられ た，AT-III 製剤投与期間中は，血小板・FDP などの改 善傾向を認める症例が多く，またAT-III 投与群は非 投与群と比較して, 消化器出血の頻度が低く, 生存率 が高い傾向を認めた。

\section{7. 劇症肝炎における血液凝固線溶動態一特に} ATIII を中心として

岩手医科大学第 1 内科

柏原 紀文, 佐々木清寿, 寺崎 公二

滝川 康裕, 加藤 章信, 吉田 倰巳

鈴木 一幸, 佐藤 俊一

劇症肝炎34例の血液凝固線溶動態と消化管病変なら びに出血との関連について ATIII の動態を加味して 検討した。劇症肝炎ではATIII は22士4\%(平均値士 標準誤差）と著明に低下したが，生存例と死亡例では 差がなく，FDP 高値例では極めて低値を示し FDP 低 値例では異常値ながら比較的高値を示した．剖検18例 の5ち胃粘膜病変を認めた13例は，認めない 5 例に比 し ATIII の低值 $(\mathrm{p}<0.05)$, Fbg の高値 $(\mathrm{p}<0.05)$ を 示し凝固六進による循環障害が想定され，実験的にす DMN 急性肝不全犬で胃粘膜血流の低下をみた。消化 管出血を認めた12例は認めない22例に比し ATIII 不 変, $\alpha_{2} \mathrm{PI}$ 低值 $(\mathrm{p}<0.05)$, plasminogen activator $の$ 高値傾向をみ，線溶え進の関与が考えられた。

\section{主題(3) その他}

1. 実験的急性肝不全の作製一自己免疫性肝炎 モデルに発症せしめた致死性肝壊死にっいて 千葉大学第 1 内科

$\begin{array}{llll}\text { 小川 } & \text { 真, 森 } & \text { 義雄, 森 } & \text { 照男 } \\ \text { 上田 } & \text { 志朗, 吉田 } & \text { 弘道, 加藤 } & \text { 功 } \\ \text { 睲元 } & \text { 亮作, 若新 } & \text { 洋子, 若新 } & \text { 政史 } \\ \text { 奥田 } & \text { 邦雄 }\end{array}$

近交系 C57BL/6 (B6) マウスに同系マウス肝抗原及 び Freund's complete adjuvant を免废して作製した 実験肝炎モデルマウスに少量の大腸菌 lipopolysaccharide (LPS) を投与する事により生じた病態生理学 的変化につき検索した。そその結果 3 回以上肝抗原を兔 度し, 肝内に細胞浸潤が強くみられるマウスにLPS 25 $\mu \mathrm{g}$ を投与すると約 $60 \% か ゙ 48$ 時間以内に死亡し,生存例 にも広範な肝壊死と LDH の上昇がみられたが他搭器 には病変を認めなかった. FCA のみ免疫したマウスに 同量の LPSを投与しても劇症化を認めず，予め細胞浸 潤を伴 5肝炎像がマウス肝に成立している事が肝不全 の発症に不可欠と思われた。更にマウス采統差につい ても検討した。 


\section{2. 実験的急性肝不全モデルと LPS の構造と} の関係

大阪市立大学第 3 内科

久保井広志, 溝口 靖紘, 木岡 清英 中東 桓, 武田 弘, 宮島 慶治

阪上 吉秀, 小林 粅三

同 第 1 生化学森沢 成司

同 細菌学 矢野 郁也

大阪社会医療センター山本 祐夫

マウスに Propionibacterium acnes (P. acnes) 加 熱死菌を静注し， 1 週後にグラム陰珄菌由来の LPS を 少量追加静注すると, 厷範な肝細胞壊死が誘導され, ほとんどのマウスは死亡する.今回はLPSをポリミキ シン B で処理することにより lipid A 部分の活性を落 とし，この処理 LPS または lipid A，またはこの両者 を静注した時の GPT, 肝組䅧について検討した。ポリ ミキシン B 処理 LPS, lipid A 単独では GPT の上昇 は見られなかったが，両者を静注したるのではGPT の有意な上昇が見られた。しかし，いずれも広範な肝 細胞壊死は起こらず，マウスは死亡しなかった。

3. Galactosamine 肝障害後の肝再生に及ほ す Putrescine $の$ 影響一Bromodeoxyuridine 酵素抗体法を用いて一 大阪市立大学第 3 内科

坂口 浩樹, 関 守一, 金 鎬俊 西口修平, 川北 啓喜, 塩見進 斉藤 忍, 㩐口 靖紘, 黒木 哲夫 針原 重義，小林 粅三 大阪社会医療センター 山本 祐夫

新しいS 期細胞同定法である，Bromodeoxyuridine (BrdU) 䤃素抗体法を用いて, Galactosamine 肝障害後の肝再生に及ぽす, putrescine の影響を検討 した. Galactosamine 単独投与に比し, putrescine 添 加群では, BrdU陽性肝細胞が増加したが, 体内の putrescine 産生を阻害する Difluoromethylornithine 投与により，BrdU 陽性肝細胞数は，激減した。 このこ とより, putrescine は, 肝再生を促進することが示唆 された。
4. 実験的急性肝不全の脳浮腫に対するマニ トールの効果

久留米大学第 2 内科

神代 龍吉, 赤司 隆裕, 古賀郁利子

力武 潔, 浜田 隆臣, 古寺 重喜

安倍 弘彦, 谷川 久一

急性肝不全の脳浮腫に対するマニトールの奻果を d-ガラクトサミン $(2.0 \mathrm{~g} / \mathrm{kg}$ ip) による急性肝不全ラッ トモデルで検討した．d-ガラクトサミン投与後48時間 目よりマニトール $(0.6 \mathrm{~g} / 30 \mathrm{~min}, 1$ 日 4 回) を点滴静 注した群では脳内水分量, $\mathrm{Na} / \mathrm{K}$ 比の低下傾向が特に 脳幹部で見られ，大脳の透過電顕像では，アストロサ イトの足突起の浮腫像が軽減された。これらの効果は 昏睡の浅いラットにおいてより大きく，深昏睡に陥っ たラットでは脳内水分量がかえって増加する場合る見 られた。

マニトールは脳浮腫を改善するが，昏睡の浅い時に より有効であり，深昏睡時には必ずしも有效ではない と思われた。

5. 安定化へモグロビン溶液を用いた normo-thermic whole body rinse-out $\sigma$ 実験的 急性薬物中毒人の応用

東京女子医科大学腎臟病総合医療センター 外科, 治療用医工学, 透析室

船越 陽一，阿岸 鉄三，本田 宏 山形 桂仁, 小林 峰德, 高橋 满彦 洸之上昌平, 寺岡 彗, 太田 和夫

安定化へモグロビン溶液を用いて全身血を置換する normothermic whole body rinse-out d digoxin 大量 静注後の実験犬に施行し, その digoxin 除去効果, 安 全性について検討した。へマトクリット值が $5 \%$ 以下 となるまで安定化へモグロビン溶液による全身血置換 を行った結果, 循環血液量の $91.5 \%$ が交換されたと推 定された。 この処置による digoxin の血中からの除去 率は92.2\%であった. 本法施行中, 血圧, 中心静脈圧, 尿量は安定していた。 血清 GOT 值, GPT 值に軽度の 变動がみられたが, BUN 値, 血清 $\mathrm{Cr}$ 值はほぼ安定し ていた，血液凝固系は，全身血置換終了直後，一過性 に異常値を示したが24時間以内に正常化した。本法は 安全, かつ血中からの病因物質除去の有効な血液浄化 法として, 将来, 急性肝不全あるいは急性薬物中毒に 対する臨床応用が期待される。 
6. 重症肝障害時のアルブミンと AFP 産生に ついての実験的および臨床的検討

久留米大学第 2 内科

吉武 正男, 野口 和典, 釈迦堂 敏 赤司 隆裕, 上野 隆登, 神代 龍吉 向故彰太郎, 安倍 弘彦, 谷川 久一

重症肝障害生存例10例での血中 AFP とALB の関 係を調べたところ, AFP とALB の間に鏡面像の関倸 がみられた。

劇症肝炎患者肝での免疫組織学的検討では, ALBが 強く染色されたものに生存例が多かった。 また，再生 した成胆管にも AFPが染色された。

70\%部分肝切除を施したラット肝での释時的な AFP と ALB 染色では, 肝切除後 3 日でALB 産生は 最低となり，AFP 産生は最高になった。 その後, ALB 産生は回復し，AFP 産生は低下した。 これらのことよ り，重症肝障害時の低 ALB 血症および高 AFP 血症 は, 肝細胞での ALB 産生低下と AFP 産生元進を反映 しているすのと考えられた。

\section{HB carrier からの劇症化についての検討} 岐阜大学第 1 内科

$\begin{array}{llll}\text { 越野 } & \text { 陽介, 松原由希子, 村上 啓雄 } \\ \text { 刘 } & \text { 沛, 加藤 則広, 星山 直基 } \\ \text { 杉原 } & \text { 潤一, 中村 俊之, 大西 弘生 } \\ \text { 畐田 } & \text { 栄一, 武藤 泰敏 }\end{array}$

HB carrier から急性肝不全様症状を呈した症例 4 例（A 群），HB carrierでシューブを来した症例20例 (B 群)，B 型劇症肝炎21例(C 群)を臨床的に検討した。 $\mathrm{A}$ 群の5 万人院時 $\mathrm{e}$ 抗原陽性のものは 2 例, IgM 型 $\mathrm{HBc}$ 抗体陽性のものは 3 例で, HAV， $\delta$ 因子, 非肝炎 ウイルスが関与したと思われる症例はなかった。 また， $\mathrm{A}$ 群は全例死亡し，剖検又は死後針生検にて，厷範な 肝壊死がみられた，A 群 (入院時) は B 群 (シューブ 時)に比し, T. Bil., Med., AAA が高く, PT, HPT は低值で，肝障害が重篤と考党られた。一方，脳症発 現時において，A 群はC 群に比し，PT は有意に高く， GPT は低い傾向がみられた。ささらに，臨床経過では， B 型劇症肝炎 (C 群)は急性型の経過をたどる例が多い (74\%)か，A 群は全例亜急性型の経過を示し, 症状発 現から脳症出現までの日数も全例25日以上（27.5日） とC群（9.9日）に比し有意に長かった。

\section{8. 薬郕性急性肝不全の特徴 山口大学第 1 内科}

田中 裕子, 佐貫 和陖, 村上不二夫 黒川 典枝, 日野 啓輔, 小西 知己 安藤啓次郎, 安永 満, 沖田 極 竹本 忠良

教室で経験した薬剂性急性肝不全10例と，ウイルス 性急性肝不全19例について，その予後および臨床経過 について比較検討した。

生存率は薬剂性で $50 \%$ ，ウイルス性で $15.8 \%$ と，急 性型，亚急性型ともに薬剤性の方が高かった。

初発症状は，薬片性で発熱，ウイルス性では消化器 症状，倦意感が多くみられた。臨床検查值では， $\gamma$-GTP が薬剤性で有意に上昇していたが，他は有意差がな かった.

重篤な合併症はウイルス性の方に多い傾向がみら れ，加えて薬剤性は，薬剤中止により影響がなくなる 可能性もあり，このことがウイルス性との生存率の差 に影響していると考えられた。

9. 特異な経過をたとった Acute on chronic の 1 例

$\begin{array}{ll}\text { 川崎中央病院内科 } & \\ \text { 住野 泰清, 柴田 } \text { 実, 秋田 博彰 } \\ \text { 定本 貴明, 岡田 } \text { 正, 佐藤源一郎 } \\ \text { 上野 幸久 }\end{array}$

症例は29歳男性, 大酒家. フルコール性肝障害の既 往あり。主訴は意識障害。昭和60年11月全身傹急感・ 黄疸出現し某院入院. 肝性昏睡II度となり重症アル コール性肝炎の診断で治療を受け退院. 以後领酒を再 開（日本酒 3 合/日）したが，昭和61年 8 月強い全身倦 忿感が出現したことを契機に断酒。しかし10月に日本 酒 4 合を 3 日間摄取したところ急激に肝性昏睡川度と なり当院に再入院した。 入院時 T-Bil $25.4 \mathrm{mg} / \mathrm{d} l$, HPT $17 \%$ と重症でフルコールによるAcute on chronic と診断したが一般的肝不全治療により救命し 得た。肝組織所見は強い脱落を伴らアルコール性肝線 維症 severe。また巨大な Porto-systemic shuntを確 認，重症化助長因子と考皇た．若年であったことと病 因が除去可能なアルコールであったことが救命しえた 理由と思われる。 
10. 血浆交換と PMMA 膜血液沪過透析による 強力な肝補助下にインターフェロン療法を 行った垔急性肝炎の 1 例

昭和大学藤が丘病院消化器内科

$$
\begin{array}{crr}
\text { 竹内ゆかり, 与芝 } & \text { 真, 平田 } & \text { 信人 } \\
\text { 菅谷 慶三, 藤田 } & \text { 力也, 菅田 } & \text { 文夫 } \\
\text { 同 腎灆内科 } & \text { 越川 } & \text { 昭三 }
\end{array}
$$

非 $\mathrm{A}$ 非 B 型覀急性肝炎は肝再生に之しく, 予後不 良といわれる。我々は血浆交換と PMMA 膜血液汇過 透析による強力な人工肝補助療法によって急性期の肝 不全を克服し，更に遷延する肝不全をインターフェロ ン療法で改善させ約 5 カ月で退院可能となった非 A 非 B 亜急性肝炎の 1 例を経験したので報告する. 症例 は38歳女性, 昭和61年 9 月急性肝炎発症, 昭和62年 1 月19日肝性昏睡II度にて入院，PT 34.6\%であった。 約 2 力月間人工肝補助療法を行い, 全身状態良好と なったが肝不全が遷延するため 4 月 1 日より $\beta$-IFN 投与を開始したところ，急激に肝機能が改善し，6月 13日に退院となった。
11. 急性肝不全に対する肝血流改善療法の試み 一劇症肝炎救命 2 症例における検討一 要媛大学第 3 内科

$$
\begin{array}{ll}
\text { 大嶋 完二, 多田 康二, 赤松 興一 } \\
\text { 宮内聡一郎, 太田 } \\
\text { 康幸 }
\end{array}
$$

非代償性肝硬变患者10例に Dobutamine を持続投 与すると，心拍出量は平均約 $20 \%$, 肝血流量は約 $4 \%$ 増加した。次いで, 肝硬変黄㾝 8 症例に 2 週間の Dobutamine 投与を行らと血清ビリルビンは約 $30 \%$ 低 下した.

劇症肝炎症例では肝血流量が低下していると予想さ れるので 2 例の劇症肝炎例に Dobutamine を投与し たところ，Hpt，GPTは良好な経過を示し改善し，2 例とも救命できた．そのうち1例においては血清ビリ ルビンの改善に Dobutamine 投与が有効であったと 思われた。この原因の1つには肝血流量の増加が関係 しているのではないかと考完, 現在急性肝不全に対す る肝血流改善療法の効果について動物実験で検討中で ある。 